DOI: $10.19195 / 0137-1150.163 .42$

\author{
JANA VRAJOVÁ \\ Univerzita Palackého v Olomouci, Republika Czeska \\ jana.vrajova@upol.cz
}

\title{
Proměna literární reprezentace stáří skrze postavu staré ženy v povídkové tvorbě autorů 80. a 90. let 19. století
}

V následujícím textu se budeme soustředit na podoby literární reprezentace stáří skrze postavu staré ženy v povídkových textech vybraných autorů druhé poloviny 80 . a 90. let 19. století. Za stěžejní jsme zvolili povídky autorů, kteří koncem 19. století zásadním způsobem utvářeli literární život jak z hlediska diskursivního, tak také z hlediska vertikální stratifikace literatury: Sofie Podlipské jakožto představitelky konvenční prózy, Terézy Novákové coby zástupkyně starší generace umělecky náročné literatury a Rudolfa Karla Zahálky — reprezentanta mladé generace vstupující do literatury koncem 19. století s nemalými literárními ambicemi. Dotkneme se též okrajově povídky Jaroslava Vrchlického Stařena, jež je dokladem diskursivního různohlasí, které je v druhé polovině 19. století evidentní, a v níž je s postavou staré ženy pracováno skrze parnasistní vidění světa. Podnětem vedoucím k zájmu o varianty literárního zpracování postavy staré ženy jako dokladu jedné z podob literární reprezentace ${ }^{1}$ stář́ bylo specifické postavení ženy — matky ve společnosti 19. století.

* Studie byla napsána za podpory vnitřního grantu FF UP FPVC2013/18 Tvorba Sofie Podlipské v kontextech a souřadnicích české literatury 2. poloviny 19. století.

${ }^{1}$ Terminologická poznámka: jsme si vědomi mnohohlasí definic, které se s termínem „reprezentace” spojují. Podle Mileny Bartlové můžeme kategorii reprezentace definovat jako „proces (a jeho výsledky), jímž se zastupuje nějaká skutečnost ve formálním aparátu lidské komunikace a vnímání; rozumí se, že tím dochází k určité redukci či jiné proměně výchozí skutečnosti." (M. Bartlová, Reprezentace, [w:] Kultura jako téma a problém dějepisectví, Brno 2006, s. 63). Bartlová rovněž upozornila na to, že pokus nahradit termín reprezentace v češtině slovem zobrazení může vést $\mathrm{k}$ př́lišnému propojení uvažování o této kategorii s hmotným (případně mentálním) obrazem (M. Bartlová, Reprezentace, [w:] Kultura jako téma a problém dějepisectví, Brno 2006, s. 65). P.A. Bílek dále zpřesnil uvažování o kategorii literární reprezentace a z jeho pojetí 
Riegrův slovník naučný ${ }^{2}$ jako první česká encyklopedie vycházející v 60 . a 70. letech 19. století heslo Stář́ neobsahuje; toto slovo konotující současný význam je zmíněno pouze pod heslem $V e ̌ k^{3}$. Ten je primárně definován jako „vůbec trvání, pásmo času... určitěji tolik co stáří, totiž čas, který člověk přežil aneb nějaká věc přestála, trvala." Součástí definice je rozdělení fází lidského života do dětského, mladého, dospělého či vysokého věku, dále je čtenáři předestřena periodizace světových dějin počínající starým věkem a končící věkem nejnovějším. O stáří v dnešním slova smyslu — tedy konečné etapě života — tu není ani zmínky. Otázky současných sociologů stárí, gerontologů či politologů, které se vztahují ke kvalitě života ve stáří jakožto finální etapě lidského života i k dalším psychologickým, sociálním či lékařským aspektům tohoto období by nejspíš nebyly tehdejší společností shledány aktuálními zejména proto, že skupina lidí dožívajících se stádia senescence ${ }^{4}$ byla relativně malá. Helena Haškovcová, profesorka lékařské etiky, jejímiž hlavními tématy odborného zájmu jsou sociální gerontologie a thanatologie, v unikátní publikaci Fenomén stárí napsala v kapitole věnované historii fenoménu stáří lapidární informaci: „počet starých lidí byl po celá staletí relativně malý, ale v posledních 60 letech [podle publikace v roce 2010 — pozn. J.V.] trvale a dramaticky roste. Lidé prostě žijí déle a odborníci hovoř́i o tzv. inflaci stáří" ". Milena Lenderová, historička dějin kultury, v knize Dějiny každodennosti , dlouhého” 19. století zpřesnila a rozšířila výše zmíněnou informaci o stanovení výše věku, jejž se lidé v 19. století dožívali:

V roce 1910 v českých zemích nepřekročil počet osob, které oslavily šedesátku, $9 \%$ z celkového počtu obyvatelstva" a připojila tabulku, z níž je zřetelné, že v osmdesátých a devadesátých letech devatenáctého století se v českých zemích sedmdesáti a více let dožila necelá tř̌i procenta obyvatel. ${ }^{6}$ Ve shodě s Haškovcovou poznamenala, že „stárnutí obyvatelstva je fenoménem 20. století." 7

V kapitole věnované analýze problematiky stář́ z historické perspektivy připsala Haškovcová právě 19. století obrat od tradované představy o „krásném stáří, která doplněna zpětnými romantizujícími pohledy žije dodnes" ${ }^{\prime} \mathrm{k}$ tendenci postupně upřednostňovat dětství a mládí a vnímat stáří jako obtížně přijatelné období života. Navzdory všeobecně rozšířené informaci o tom, že byl Jaroslav

v našem uvažování vycházíme. Podle něj ,jádrem fungování reprezentace v literatuře je ... složité dění, jež probíhá v samotném sémantickém procesu. Výraz v literárním textu je z hlediska našeho vnímání a rozumění, jež se odehrává aktem čtení, začleněn do dynamické, bohaté a problematicky rozčlenitelné oscilace mezi označováním a odkazováním.” (P.A. Bílek, Reprezentace: Metafora, pojem či koncept? [w:] Jazyky reprezentace, Praha 2012, s. 15).

${ }^{2}$ Vycházel v nakladatelství Ignáce Leopolda Kobera v letech 1860-1874.

${ }^{3}$ Díl, v němž je toto heslo obsaženo, vyšel v roce 1874.

${ }^{4}$ Definice podle Světové zdravotnické organizace, viz H. Haškovcová, Fenomén stáří, Praha 2010, s. 20

\footnotetext{
5 Ibidem, s. 19.

6 M. Lenderová, Dějiny každodennosti „,dlouhého” 19. století, Pardubice 2005, s. 69.

${ }^{7}$ Ibidem.

${ }^{8}$ H. Haškovcová, Fenomén stáří, Praha 2010, s. 33.
} 
Vrchlický v době svých padesátých narozenin oslovován „slovutný kmete” Haškovcová připomněla, že ,úcta ke starým občanům však ani v minulosti nebyla pravidlem a nezřídka se staří lidé museli o úctu ostatních doslova rvát"'. Milena Lenderová z pozic kulturně historických zdůraznila, že $\mathrm{k}$, jistému ocenění stáří dochází teprve s osvícenstvím." 10 Postupně se v tomto období vytvářel obraz moudrého starce a evropské literatury začaly pracovat se stereotypem „moudrého stáří” — v souvislosti s českým kontextem Lenderová připomněla Babičku Boženy Němcové a Raisova Pantátu Bezouška ${ }^{11}$.

Tento sociologický exkurz jsme považovali za nutné učinit proto, abychom si připomněli kulturní odlišnost společnosti 19. století vedoucí v našem prŕpadě k uvědomění si faktu, že za staré byli mnohdy označováni ti, kteří již vychovali děti; bez ohledu na to, jak vysokého byli věku. Nejzřetelněji to bude prokázáno na povídce Sofie Podlipské Staři a mladí, ovšem ani postavy Raisových výminkářu (at' už se jedná o mužskou či ženskou postavu) mnohdy nejsou charakterizování věkem. $Z$ analyzovaných autorů pouze Teréza Nováková dbala ve svých povídkách na uvedení věku vykreslovaných postav, čemuž rozumíme jako dokladu jejího vědomého a reflektovaného př́klonu $\mathrm{k}$ realistickému diskurzu.

$\mathrm{Z}$ hlediska literárněhistorického pro nás bude vzhledem $\mathrm{k}$ charakteru zkoumaných textů zajímavá proměna reprezentace stáří jako idyly (odvíjející se od šlechetných vlastností připisovaných starým lidem jako je moudrost, laskavost, trpělivost) $\mathrm{k}$ reprezentaci stáří, jež doprovázejí jednoznačně negativní atributy (nemoc, hrůza, strádání). ${ }^{12}$ Vzhledem k produktivitě žánru venkovské prózy ve sledovaném období je logické, že většina sledovaných textů (s výjimkou románu Sofie Podlipské Lidské včely) je ukotvena právě v prostoru venkova.

Že se kulturní veřejnost konce devatenáctého století polarizovala ohledně otázky zobrazení venkovského života, je známým faktem, souvisejícím s nacionalizací toposu české chaloupky, který se, jak připomněl Vladimír Macura, stal klíčovou „součástí národní sebereflexe,” ustalujícího se mýtu českého národa. ${ }^{13}$ Aleš Haman v Trvání v proměně zdůraznil, že od 80. let ztrácí venkov v literatuře kulisovitý ráz a stává se důležitou determinantou lidských charakterů ${ }^{14}$. Jaroslava Janáčková popsala nezjednodušujícím způsobem různé druhy motivovanosti obliby venkovské tematiky ${ }^{15}$.

\footnotetext{
${ }^{9}$ Ibidem, s. 34.
}

${ }^{10}$ M. Lenderová, op. cit., s. 71.

11 Ibidem.

12 Tato změna je registrována $\mathrm{v}$ širším kulturním prostoru, nikoli pouze v literatuře. Haškovcová ji ve zmíněné knize registruje, neuvádí však její důvody; píše, že se udála „z ničeho nic” a „nepochopitelně” (H. Haškovcová, Fenomén..., s. 34).

${ }^{13}$ V. Macura, Idyla a česká chaloupka, [w:] Idyla a idyličnost v kultuře 19. století: sbornik př́spěvků ze sympozia uspořádaného 9. a 10. března 1995 ve Státní vědecké knihovně v Plzni, eds. K. Kaiserová, I. Martinovský, Ústí nad Labem 1999, s. 12.

14 A. Haman, Trvání v proměně, Praha 2010, s. 273.

15 J. Janáčková, Stoletou alejí, Praha 1985, s. 165 n. 
V souvislosti s proměnou diskurzivity české literatury druhé poloviny 19. století, tedy s postupně se prosazující realistickou techné, se idylizační koncept zobrazení venkova zástupně reprezentovaný Babičkou Boženy Němcové rozbíjel, což bylo doprovázeno polemickými střety. Jak silné tyto spory byly ještě v posledním desetiletí 19. století, je patrné např́íklad z dobové recenze Raisových $V y$ minkář̀o z pera Terézy Novákové, kterou uveřejnila v biedermeierovském duchu vedeném olomouckém časopise Domácí hospodyně v roce 1891:

On Výminkáři rozluštil spor jaksi dosti zuřivý, způsobem zcela klidným a přirozeným. Pokud se povídek a románů z lidu týče, jest roztržena naše veřejnost př́íře na dva tábory; jedni přejí si viděti základ národa, lid vesnický, jen v barvách nejskvělejších, jsou pevně přesvědčeni, že najdeš v něm ideálných postav množství, umíš-li si je vyhledati, a hluboce jsou uraženi, líčí-li kdo o lidu co nepěkného, hnusného, tvrdého, nenávidíce v takovém básníku — spisovatele téměř zrádce, nevlastenče, cynika. Druzí prostě upírají, že ideální líčení z lidu, ti hrdinové a hrdinky jsou čímsi jiným než naprostou lží básnickou; tvrdí pevně, že v lidu je pouhý shon po „mamoně”, že mravní pojmy jeho jsou z nejspletenějších a základy mravní v nejslabších, že ten, který pravdivě chce líčiti lid, musí sáhnouti k barvám, at’ tak díme Zolovským. Kdo z nich má pravdu? Obě strany jistou měrou. V lidu, ten kdo hledat umí, nalezne postavy ideálně, hrdiny bud' činu neb citu, ale ne vždy a ne zhusta — právě jako mezi ostatní společností; v lidu také jest mnoho tvrdosti, mnoho mamonářství, jeho pojmy mravní jsou často velmi laxní, poměry rodinné rozhárané aneb na prospěchářství zbudované — také jako mezi ostatními tř́́dami. Měli by snad proto novelisté a básníci vyhýbati se lidu jako předmětu své tvorby, lidu, který ve své dobrotě i zlobě, ve své něžnosti i tvrdosti, ve své vášni i ve svém mamonářství je svým, svérázným? Příkré ty protivy velice štastně, umělecky štastně, spojil ve svých Výminkářích Rais; ani mu nepřipadá, aby nějaký tvrdý rys svých postav potlačil, něčím ideálním k nim nenáležejícím je přizdobil — ale tam, kde si něžnou mysl jako kontrast světelný vynašel, vykreslil ji taktéž zcela pravdivě, rázovitě, nelíčeně. ${ }^{16}$

Výše připomenutý spor bude v základech našeho dalšího uvažování.

\section{Dvakrát Sofie Podlipská — podoba staréženy v konvenční próze}

Roku 1884 vydala etablovaná spisovatelka zejména výchovných textů a povídek pro mládež Sofie Podlipská prózu Staři a mladí. Měla za sebou v té době již zkušenost s povídkovou i románovou tvorbou, povídku vydala u Mamerta Knappa, nakladatele, který navázal na práci Ignáce Leopolda Kobera. Adjektivum staří v názvu povídky konotuje, jak již bylo avizováno, nikoli stáŕí, ale generaci rodičů, mladí jsou pak dospívající děti. Rámec povídky je idylický; Podlipská vědomě pracovala s toposem moudré stařenky, asociující laskavostí postavu Babičky Boženy Němcové, když jej utvářela: narativ začíná setkáním a společnou cestou vypravěčky se starou ženou (,stará, shrbená babička" ${ }^{\prime 17}$ ). Ta cestou vypráví př́íběh dvou rodin prožívajících různé podoby manželské krize, jehož průběh je na rozdíl od idylického

16 T. Nováková, K sestrám československým, „Domácí hospodyně” 8, 1891, č. 16, s. 351.

17 S. Podlipská, Staři a mladi, Praha 1884, s. 5. 
rámce zobrazen realisticky. Na specifičnost v povídce vykresleného prostoru vesnice vzhledem k zažité představě je čtenář dopředu upozorněn:

To je nejbohatší vesnice v celém okolí. Není v ní jediné chaloupky. Celá ta veliká ves chová v sobě jen čtyři statky. Vesnice podobala se více upevněnému hradu nežli veselé dědině české, kde všecko ze vrátek vybíhá, když povoz zdaleka zarachotí, kde bělohlavé, košilaté děti přebíhají — pokřikují a staré babičky na prahu sedíce brambory na polévku loupají... ${ }^{18}$

Ústředním motivem povídky je právo na sňatek z lásky, nikoli racionálního kalkulu. Překvapivě se v ní však objevuje emancipační tendence s větší razancí, než bychom u Podlipské, jejíž texty zpravidla směřovaly k smířlivému gestu zrozenému v tradici konvencionalizovaného biedermeieru, čekali. V povídce se totiž neobhajuje pouze láska mladých, jejich rozhodnutí ke společnému budoucímu životu, ale nečekaně i právo předchozí (tedy staré) generace ve svazku bez lásky nesetrvat. Dalším překvapením pro čtenáře může být fakt, že se k odchodu z letitého manželství neodhodlává psychicky týraná žena, jak bychom možná v očekávání stereotypu (jehož využití $\mathrm{v}$ prrípadě konvenční prózy má čtenář právo očekávat) předpokládali, ale muž. ${ }^{19}$ Nakonec je pokáním na jedné straně a odpuštěním na straně druhé konflikt vyřešen smírem a udržením manželského svazku, z narativu je však evidentní, že ani konvence ani mravní vyspělost jedné z vykreslených postav nejsou pro autorčino morální sdělení tím, co má sílu udržet rodinné svazky pohromadě. Tím stěžejním je osobní, individuální štěstí pramenící z oboustranné lásky a završené manželským svazkem jednoty v různosti. Postava moudré a laskavé babičky $\mathrm{z}$ rámce povídky, jenž je zárukou pravdivosti vyprávěného a zároveň dokladem možnosti navzdory životním peripetiím dospět k idylickému stáŕí odkazujícímu k literární tradici Babičky, i proměna vnějšího obrazu venkovského prostoru (bohatství - prosperita, nikoli chudoba) má být dokladem a dotvrzením funkčnosti a smysluplnosti volby takového modelu života. ${ }^{20}$

18 Ibidem, s. 3-4.

${ }^{19}$ Když rozšiŕíme naše uvažování o obecně kulturní souvislosti týkající se rozvodu či rozpadu manželství (v roce 1880 bylo podle M. Lenderové v celém Rakousku pouze 2957 rozvedených či rozloučených osob), pak byla práce s motivem odloučení manželů vysoce moderním rysem prózy Podlipské.

${ }^{20}$ Literárně historická vsuvka: Povídka vyvolala v době vydání polemiku na stránkách Literárních listů. Kritik H. Pittauer napadl věrohodnost kresby venkovských postav zejména v rovině dialogů (de facto vytkl Podlipské nedostatečné realistické ukotvení textu), ale nejvíce jej rozhořčilo označení textu jako „povídka pro lid” . „Venkované nevyjadřují se tak jako vzdělanci, a spisovatelka chybila kladouc jim do úst elegantní obraty vzdělanecké řeči; iluze je tím úplně změtena, vyhlazena. Je to venkovanka z jádra, která sentimentálně volá: »Ó, slzy, slzy, pojd’te mi ulehčiti,« nebo vesnický junák, který deklamuje: „kéž vaše přání mou žádost', moje štěstí posvětí (!) a potvrdí!” To nejsou postavy z lidu, to jsou figury imaginární; kterak možno sloučiti prostý rozum, prajednoduché myšlení lidu s umělým, vybroušeným promlouváním, jak to shledáváme $\mathrm{v}$ této povídce? Třeba se $\mathrm{s}$ důrazem vysloviti proti takovémuto pohodlnému skládání povídek „,z lidu.” Kritik požadoval věrohodné zobrazení prostoru venkova a pozastavil se nad tím, že se mu zdálo, že si autorka ,ani nevytkla za hlavní úkol zachovati věrně barvy skutečnosti ve spise svém". Požadavek věrohodnosti souvisel s požadavkem budování národní literatury: „To bychom se dodělali pěkné literatury národní, původní, české, kdyby se i ten náš, 
Podlipská ve svých prózách často tematizovala generační střety, postavy stárnoucích žen v jejích dílech většinou prošly určitou katarzí a došly životní moudrosti. Nejzajímavěji a pro její způsob literárního vyjadřování netypicky zpracovala charakter staré ženy v románu Lidské včely (1889). Téma zkrachovalé bohaté rodiny, jejíž členové se snaží zařadit do společnosti a prosí o pomoc př́ibuzné, kteří je dříve zavrhli, zasadila do prostředí jí důvěrně známého — do pražských salónů. Víceméně epizodní postava staré bezdětné Leni žijící ve společné domácnosti pouze se svým bratrem je k sobeckosti a hamižnosti determinována prostředím, v němž vyrůstala:

Ale jak hospodařili, jak dřeli se ti dva lidé, aby sobě zbudovali toto obydlí pro ně nádherné: Děti, Leni, Petr a Pavel, byli vychováni v tom zápasu o kousek majetku, a Leni pochopila ideu toho namáhání tak, že jí toliko své žití věnovala a nikdy se neprovdala. Po smrti své matky hospodařila ona otci a bratrům a skrblila, lakotila tak, že jim ztrpčovala život. ${ }^{21}$

Citová slabost vyvolaná na kolenou prosícími dětmi př́íbuzných v Leni způsobí dočasnou empatii k trápení rodiny, která se ocitla bez prostředků i živitele rodiny (otec je vykreslen jako zdánlivě silný muž, který se však ze strachu z ženiných výčitek snažil defraudací udržet vysoký standard chodu rodiny; zřejmě pod tíhou viny přirozenou smrtí ve spánku zemřel). Když je však vykradena Lenina tajná skrýš, do níž si od dětských let spořila, obviní ty, jimž neochotně pomáhala, ze zlodějny a sama pak umírá na mozkovou př́íhodu. Na smrtelném loži, kdy žádá svého bratra o odpuštění, se jí však její celoživotní sobeckost vrací v nečekané podobě; bratr jí vyčítá, že tím, že zamlčela přede všemi své bohatství, je vlastně všechny okradla:

Odpustit, odpustit mám? Ach, mám toho př́iliš mnoho na srdci proti ní. A ted’ odchází a béře do hrobu klíč ke svým pokladům. Ani po smrti jich nepřeje. Dokud mohla mluvit, nechtěla udat ze zášti znaky, dle kterých bychom se jich zase domohli. Ted' nemůže již mluviti. Byla okradena, ale sama okrádá nás. Ano, ty nás okrádáš!” zvolal. Ona dívala se na něho s hrůzou nevýslovnou. Ten ubohý obličej stahoval se k nepoznání, ruce hledaly jedna druhou, aby se k prosbě sepjaly. Ale nenašly se již v tomto životě ani ku práci, ani ke prosbě. ${ }^{22}$

Naturalistickým zobrazením momentu umírání doprovázeného nikoli porozuměním a odpuštěním, ale hrůzou, je citovaná pasáž typologicky blízká s popisem

beztoho vadnoucí národní život venkovského lidu, měl falšovati a do kosmopolitické bezbarevnosti odívati. Kdo chce psáti o lidu našem, at' jde mezi něj, at' s ním obcuje vnitřně při každé významné př́ležitosti, at' se účastní jeho obyčejův a zvykův, at' si osvojí jeho ráznou, př́padnou a barvitou mluvu, at' pozná jeho morální smýšlení a vyspělost’ rozumovou: pak teprve může psáti povídky z lidu." Výtce „kosmopolitické bezbarevnosti” rozumíme jako kritice směřující primárně do tematického plánu, jeho nepropracovanosti, z nějž následně vyrostly i nedostatky v plánu jazykovém (již zmíněné salónní dialogy pronášené postavami vesničanů). Na recenzi zareagoval v témže periodiku Václav Špaček, redaktor nakladatelské řady Nové knihovny pro český lid, v níž povídka Podlipské vyšla jako její druhý svazek. Obhajoval text, odmítal, že by „„̌tenář z lidu” povídce neporozuměl, a odsudek označil za přenáhlený, protože stojící na několika pečlivě vyhledaných větách, které by byly „V ústech lidu neobvyklé”. Z průběhu polemiky je zřetelné, že se primárně týkala vyjednávání pravidel žánru venkovské povídky. Podlipská ovšem nepsala venkovskou povídku, psala povídku moralizující, osvětovou, kterou pouze zasadila do venkovského prostředí.

${ }^{21}$ S. Podlipská, Lidské včely, Praha 1901, s. 9-10.

22 Ibidem, s. 136-137. 
Faimonova skonu v Dětech čistého živého Terézy Novákové, byt' v druhém prŕípadě se jedná o metafyzickou úzkost z nicoty, posmrtné prázdnoty. Popis umírání Leni je dokladem toho, že Podlipská jako autorka nezastírající zájem o své čtenáře neustále pracovala na stylizaci svých textů a vědomě pracovala s podněty, které českou literaturu formovaly; $v$ daném př́padě $\mathrm{s}$ impulzy naturalizmu (determinismus, popisná pasáž zaměřená na zobrazení hrůzy a úzkosti). Ty jí pomohly na postavě staré panny Leni vykreslit obraz jedné z podob neštastného stáŕí, které bylo utvářeno celoživotní honbou za majetkem bez schopnosti altruismu.

\section{Realistická povídka Terézy Novákové}

Intenzitou realistického obrazu venkova i kritikou jeho společenských poměrů jsou ve sledovaném období spolu s texty Karla Václava Raise (které ovšem nebyly předmětem našeho výzkumu, byt' by jimi bylo možno studii výrazně rozšiřit) nejvýraznější povídky Terézy Novákové z počátku 20. let; typologická či spíše diskurzivní blízkost obou autorů byla již naznačena zmínkou o tom, jak vřele doporučovala právě tato spisovatelka českým ženám Raisovy povídky.

Stará žena je ústřední hrdinkou dvou povídek Novákové ze souboru Úlomky žuly (1902), totiž Drobová polévka (napsána 1893) a S nůšsi (napsána 1894). Postava staré Chlebounky, stěžejní postava povídky Drobová polévka, je charakterizována i věkem: „Byla kdysi před šedesáti sedmdesáti lety švarným d’oučetem nyní je málem devadesátiletá Chlebounka skorem žebračkou a ostává v chaloupce u Boštíků jen tak z milosti." 23 Stařenka Loučková z povídky $S$ nůší je ovšem také nazvána stařenou, „ač jí nebylo mnohem více než šedesát rokủ." ${ }^{24}$ Jakkoli je u Novákové (podobně jako u Raise) patrné, že popisuje etapu stárí jako nezpochybnitelný konec života, věkový rozptyl při označení člověka za starého dává tušit, že starým byl vnímán ten, kdo měl dospělé samostatné děti.

Postavy stařen z obou povídek jsou charakterizovány podobně: jsou zbožné, vydané a odevzdané vyšší moci, jíž svůj život podřizují. Chlebounce Nováková dokonce připsala repliku, $\mathrm{v}$ níž vidí podstatu rodinných problémů právě $\mathrm{v}$ nedostatku víry: „Už to ten svet tak nese, — že děti o rodiče nedbaj dř́íu tak nebejvalo — ale ted'kom se lidi spustili Pána Boha." 25 Kromě využití stereotypního vnímání minula jako „starých dobrých časư”, které je z výše uvedené citace patrné, pracovala Nováková v Drobové polévce i se stereotypem „požehnaného vysokého věku", vytvářejícím kontextovou ironii. Do popisu emočně vypjaté situace, v níž si stařena se svou dcerou naříká nad tím, že jí její bohatý syn neposlal ani hrnek polévky ze zabijačky, přijde nečekaně na návštěvu mladá žena, která se ze slušnosti ptá po zdraví stařenky. Do její odpovědi Nováková zapracovala charakteristiku onoho bezútěšného stáŕí: „Holečku zlatej, — sem pořád jakási daremná —

\footnotetext{
23 T. Nováková, Drobová polévka, [w:] Úlomky žuly, Praha 2001, s. 7.

24 T. Nováková, S nůší, [w:] Úlomky..., s. 33.

25 T. Nováková, Drobová..., s. 12.
} 
spát nemůžu — modlím se kolikrát celičkou noc — tř́i růžence dycky přemodlím — bolej me nohy, ruce - málo vidím i slyším. Už po me nic nejní." ${ }^{26}$ Nováková nechala pětadvacetiletou dívku odpovědět podle dobrého mravu a konvencí, zároveň však s evidentní lehkostí nezkušeného mládí slovy: „Dyt' ste čerstvá dost, jen aby nám dal Pánbůh takovýho věku, nedočkáme to žádnej, že, tetičko?"27

I vnější charakteristika stařenek z obou povídek se podobá: ženy jsou shrbené, ústa mají bezzubá, Chlebounce jsou navíc vzhledem $\mathrm{k}$ věku ještě připsány „úplně bílé vlasy", vyhaslý pohled a slepota jednoho oka. V povídce $S$ nůši však je patrná postupující subjektivizace textu, k níž Nováková postupně ve své tvorbě přecházela. Je-li v předchozí povídce postava staré ženy označována podle místní tradice př́ijmením, př́ípadně přidáním adjektiva „stará”, pak v povídce $S$ nưši je př́ijmení od počátku stř́ídavě doplňováno přízviskem babička či stařenka. Trpký osud stařenky Loučkové, která se po smrti milované maličké vnučky, o kterou k stáru pečovala, upnula jen na pěkný pohřeb, přičemž nakonec zemřela ve špitálu a byla pohřbena jako žebračka bez obřadu, už však není zasazen do myšlenkového kontextu podřízenosti Boží vůli. V závěru povídky je zdůrazněna lidská vina za nedůstojný skon staré ženy, je rozporována osudovost. Když paní učitelová vzpomíná na babičku Loučkovou, vybavují se jí její slova o tom, že Pán Bůh trestá do třetího i čtvrtého pokolení. Těmi si odůvodňovala svůj těžký život. Teréza Nováková však tento názor zproblematizovala, když paní učitelová „uvažuje, měla-li stařena pravdu, vidouc v celém svém přenešt’astném žití, trest shůry, trest od Pánaboha'."28

V povídkách Novákové idylizační tendence zcela absentuje. Podrobné líčení zoufalství starých žen mělo čtenářem otřást, subjektivizace textu tuto intenci jen posiluje. Nováková vylíčila stáří na venkově skrze bolest duše žen - matek. Její obraz stáří je kolorován samotou, steskem, sociálním vyvržením, hmotnou nouzí. A součástí vnější charakteristiky postav starých žen z povídkového souboru Úlomky žuly bylo vykreslení atributů těchto nedostatků realistickou techné.

\section{Parnasistní vsuvka — trapné stáří}

Postavu staré ženy v druhé polovině 80. let zpracoval prozaicky Jaroslav Vrchlický v črtě Stařena, kterou zařadil do Povídek ironických a sentimentálních (1886). Dvoustránkovou skicu je třeba interpretovat s vědomím parnasistního uměleckého gesta, jemuž byla Vrchlického tvorba podřizena. Čtenáři je nabídnut obraz staré ženy sedící na mezi, v jejíž blízkosti si hraje malé dítě, aniž by jí věnovalo pozornost. Evidujeme atributy stáŕí jako „vrásčité, opálené, tvrdé, kostnaté ruce” či „,sporá šedivá kštice". Vztah mezi dítětem a stařenou není specifikován, vypravěč nabízí možnost, že žena by mohla být chůvou dítěte. Pro interpretaci tato informace zjevně není nezbytná, protože črta směřuje $\mathrm{k}$ popisu pocitu vypravěče, který v něm sledovaná

\footnotetext{
${ }^{26}$ Ibidem, s. 16.

27 Ibidem.

28 T. Nováková, S nůší..., s. 82.
} 
scéna vyvolala. Ten je vyjádřen slovem trapně. Jediným slovem Vrchlický ve zkratce obsáhl to, co Rais i Nováková potřebovali postihnout v detailech: osamělost stáŕí a nedostatek vděku následujících generací: „Obraz této divné stařeny působil na mě trapně; zdálo se mi, že vidím člověčenstvo umořené, upracované, uštvané, stydící se za výsledky své práce a přece nastavující ustavičně své ztýrané ruce paprskům světla!"’29

\section{Rudolf Karel Zahálka: Babiččin pohřeb}

Posledním, jehož text chceme v souvislosti s tematizací stáŕí skrze postavu staré ženy na konci 19. století připomenout, je Rudolf Karel Zahálka. Dnes zapomenutý autor inklinující $\mathrm{k}$ naturalismu zemřel $\mathrm{z}$ vlastního rozhodnutí v důsledku depresí ve dvaatřiceti letech. Jeho povídka Babiččin pohřeb vycházela na pokračování ve třech číslech populárního „Světozoru” v roce 1891. Povídka začíná př́ijezdem studenta Pavla na Vánoce domů. Brzy po jeho př́ijezdu však rodina obdrží dopis od dědečka, že babička zemřela, vydá se tedy s otcem na pohřeb. Následuje rozsáhlá idylická pasáž vzpomínek na dětství s babičkou evokujících harmonizační gesto Babičky Boženy Němcové. Charakteristika babičky je zjevná ze slov sousedek, které se sešly v domu smutku: „Ta jakživa nikomu neublížila. Ba ne — a každý ji měl rád.” ${ }^{30}$ Intertextualita odkazující k Němcové je posléze patrná z pasáže, kdy Pavel vzpomíná na chvíle, kdy mu babička vyprávěla: „Babička s klokočovým růžencem v ruce vyhřívala se na sluníčku a k ní se tulil Pavel, poslouchaje se zatajeným dechem a záŕícíma velikýma očima nesčetné její pohádky a vypravování, pronášené jímavým, poněkud tremolujícím hlasem."31 Že je idyla vytvářena právě vzpomínkami na období dětství, Zahálka zdůraznil slovy: „A slunce při tom tak krásně svítilo, lípy tak libě voněly a bzukot celých rojů včel na kvetoucích lipách zněl tak melodicky, jak už nikdy, nikdy potom." 32 Ze vzpomínek Pavla vytrhne pohled na máry a rakev. Idylický popis vzpomínek je v tu chvíli nečekaně vystřídán úvahou o determinantě dědičnosti: „Když tak na ni hleděl, vyrojily se nad práh vědomí všechny teorie o dědičnosti, atavismu atd., jež byl kdysi pracně studoval a zcela přirozeně následovala myšlenka: Které vlastnosti jsem zdědil? Která část mrtvé této babičky žije dále ve mně?"33 Následující závěrečná pasáž povídky, v níž Pavel srovnává svůj život s babiččiným, je textem jako stvořeným pro budoucí historiky mentalit:

Babička ve svém životě nepřestala pracovati - Pavel byl dost upřímný, aby si přiznal, že pracovat dosud ani nezačal. Babička za práci klidila jen nevděk - Pavel za nepatrnou práci mnohdy nezasloužené uznání. Babička snášela všecko s odevzdaností do vůle boží. Hleděla do hrobu nejmilejším svým dětem, pracně nashráněného jmění několikráte požárem pozbyla, zakusila bídy, žalu a protivenství, ale vždy se potěšila: ,Co Bůh činí, dobře činí — budiž jméno Páně

\footnotetext{
29 J. Vrchlický, Stařena, [w:] Povídky ironické a sentimentální, Praha 1886, s. 27.

${ }^{30}$ R.K. Zahálka, Babiččin pohřeb, „Světozor”, Praha 1891, č. 27, s. 322.

${ }^{31}$ Ibidem, s. 326.

32 Ibidem.

33 Ibidem, s. 337.
} 
pochváleno!' Nepřítele svého slovem zlým se nedotkla a v nejtrpčí chvíli, kterou jí způsobil, potěšila se tím, »že ho taky Pán Bůh vidí.« Pavel nesnesl nic, urážku okamžitě splácel urážkou, ránu ranou, kopnutí kopnutím. Babička z každé př́iznivější události dětinsky se radovala - Pavel každou radost si pokazil protivným rozbíráním, kterému každý pocit svůj hned podroboval. Babička věřila skálopevnou, dojemnou vírou, která v neštěstí vlévá do duše upokojení, naději a mír. Pavel byl skeptik nejchladnější. Hlavu měl napěchovanou nejrozmanitějšími vědomostmi... znal literatury světové i medicínu, ale nevěřil ničemu. [...] Babička byla žena prostá, ale ctnostná — kdežto Pavel poznal už dávno bahnité hlubiny hříchu a rafinovanosti velkoměštá$\mathrm{ka}^{34}$

Srovnání kulturně společenského pozadí osudů babičky a vnuka ústí v otázku, která je zopakována $\mathrm{v}$ závěru povídky: „Tak co to znamená pro naši rodinu? Od babičky až do mne — jest to pokrok? Či degenerace? Nebo pouhá metamorfóza?"35 Centrálním motivem Zahálkovy povídky není proměna životního stylu generací dědů a vnuků. Je v ní velmi subtilně zachycena proměna kulturního klimatu doby konce 19. století stejně jako vědomá reflexe nabídek soudobé moderní společnosti a otevřených cest poznání, které však zároveň přinášejí definitivní zánik možnosti nazírat svět kompaktně a neproblematicky. Je v ní ovšem též patrná i literární polemika s tradicí idylizace venkova: idyla venkova je ponechána vzpomínkám, tedy minulosti. Patř́ světu babiček, at' už s malým či velkým B. Razantní proměna diskurzivní charakteristiky třetí části textu směřuje $\mathrm{k}$ naturalistické skepsi zakládající otázky po smyslu života, dědičnosti, volněji i po významu rodinného soužití.

Závěrem: Texty autorů, jimž jsme věnovali pozornost v souvislosti s reprezentací stáří skrze práci s postavou staré ženy, jsou pro nás na jednu stranu potvrzením nikoli neznámé teze o proměně literárního zpracování venkovské tematiky, která se od 80. let 19. století v české literatuře odehrávala. Zároveň jsou dokladem koexistence a konkurence literárních diskurzů 80. a 90. let 19. století i vnitřních polemik, které soudobá literatura vedla (např́iklad o žánr venkovské povídky). Postava staré či stárnoucí ženy nabývala podob podřízených funkci textu. Tak u textů Sofie Podlipské směřujících primárně k ženskému čtenáři byla navzdory pokusům absorbovat dobové diskursivní trendy a líčit postavy i konflikt realisticky až naturalisticky nejvýraznější funkce výchovná, jíž ovšem Podlipská zcela záměrně své práce podřizovala. Venkovské staré ženy ztvárněné Novákovou vykazují atributy stáŕí jako období plného bolesti tělesné i duševní, zoufáním nad vlastními milovanými dětmi. Jsou podřízeny estetickému imperativu realismu, který u Novákové na přelomu století dominoval. Zahálkův Babiččin pohřeb je, domnívám se, z dnešního pohledu možno označit za subverzivní text a interpretovat jej nejen jako doklad pronikajících naturalistických tendencí, ale též v symbolické rovině: jako pohřbívání neproduktivních idylizačních stylizací venkova.

\footnotetext{
34 Ibidem, s. 338.

35 Ibidem.
} 


\section{Bibliografie}

Bartlová M., Reprezentace, [w:] Kultura jako téma a problém dějepisectví, Brno 2006.

Bílek P.A., Reprezentace: Metafora, pojem či koncept?[w:] Jazyky reprezentace, Praha 2012.

Haman A., Trvání v proměně, Praha 2010.

Haškovcová H., Fenomén stáří, Praha 2010.

Janáčková J., Stoletou alejí, Praha 1985.

Lenderová L., Dějiny každodennosti ,,dlouhého” 19. století, Pardubice 2005.

Macura V., Idyla a česká chaloupka, [w:] Idyla a idyličnost v kultuře 19. století: sborník př́spěvkù ze sympozia uspořádaného 9. a 10. března 1995 ve Státni vědecké knihovně v Plzni, eds.

K. Kaiserová, I. Martinovský, Ústí nad Labem 1999.

Nováková T., Děti čistého živého, Praha 1966.

Nováková T., K sestrám československým, „Domácí hospodyně” 8, 1891, č. 16.

Nováková T., Úlomky žuly, Praha 2001.

Pittauer H. (pod zkratkou -aue-), K obraně p. Špačkově, „Literární listy” 1884.

Pittauer H. (pod zkratkou -aue-), ref. Staři a mladi, „Literární listy” 1886.

Podlipská S., Lidské včely, Praha 1901.

Podlipská S., Staři a mladí, Praha 1884.

Špaček V., Několik slov k posudku povídky „Staři a mladi“, „Literární listy” 1884.

Vrchlický J., Stařena, [w:] idem, Povídky ironické a sentimentální, Praha 1886.

Zahálka R.K., Babiččin pohřeb, „Světozor” 1891.

\section{Forms of literary representation of age through changes in characters of old women in Czech short stories of $80 \mathrm{~s}$ and 90 s of the 19 th century}

\section{Summary}

The study deals with different representations of the character of old women in Czech literature of the second half of the nineteenth century. It focuses mainly on three short stories which show except of the literary image of old age also the proof of the vertical stratification of Czech literature of the end of the nineteenth century. The study also shows the literary controversy related to literary movements and intertextual relations. The latest short story which the study refers to is called Babiččin pohřeb and was written by Rudolf Karel Zahrádka. It has a specific position in the context of thinking about the use of motifs associated with old age: not only could it be characterized as a subversive text due to the intertextual passages referring to Babička by Božena Němcová, but it can be also identified as a proof of the penetration of the modernistic tendency in Czech literature.

Keywords: Sofie Podlipská, Teréza Nováková, Rudolf Karel Zahálka, realism, discourse, subversion, idyll, age 


\section{Obrazy literackich reprezentacji starości na podstawie postaci starej kobiety w opowiadaniach autorów $\mathrm{z}$ lat 80. i 90. XIX wieku}

\section{Streszczenie}

Artykuł dotyczy sposobu reprezentacji postaci starej kobiety w literaturze czeskiej drugiej połowy XIX wieku. Autorka skupia swoją uwagę zwłaszcza na opowiadaniach, które, oprócz literackiego obrazu starości, są również wertykalną stratyfikacją czeskiej literatury końca XIX wieku, jej wewnętrznych dyskursywnych polemik i związków intertekstualnych. Jako najbardziej interesujące jawi się opowiadanie Rudolfa Karla Zahálki Babiččin pohřeb, które można, biorąc pod uwagę związki intertekstualne, oznaczyć za tekst subwersyjny i pokazać na jego podstawie przenikanie do literatury czeskiej tendencji naturalistycznych.

Słowa kluczowe: Sofie Podlipská, Teréza Nováková, Rudolf Karel Zahálka, realizm, dyskurs, subwersja, idylla, starość 